\title{
The Readiness of Nahdlatul Ulama Surabaya University (Unusa) to Be the Centre of Development of Rahmatan Lil Alamin Entrepreneur (EnPlus)
}

\author{
Mohamad Yusak Anshori*, Tri Siwi Agustina*** \\ "Economic and Business Faculty of Universitas Nahdlatul Ulama Surabaya \\ **Economic and Business Faculty of Universitas Airlangga Surabaya \\ email:yusak.anshori@Unusa.ac.id", agustina2772@gmail.com***
}

\begin{abstract}
Brush (2014) states that to make the student having the spirit of entrepreneurship they have to develop start-ups in term of realizing a university venture and also to give benefit for the society, therefore, an ecosystem that is called Entrepreneurship Education Ecosystem is needed. Unusa is one of the universities in Indonesia that has a strong vision to prepare a generation having spirit of Rahmatan Lil Alamin entrepreneurship based on Islamic values. The objective of this paper is to describe the readiness of Unusa to be a university with Islamic values under the Nahdlatul Ulama organization to be the Entrepreneurship Ecosystem from the aspect of Brush's theory (2014). From the result of this discussion it is find out that in spite of only six years old in age Unusa has some breakthroughs to develop the entrepreneurship education ecosystem. However, it is urgent for Unusa to develop Business Incubator seeing that the number of Unusa students are more and more from years to years. Such fact cannot be separated from the mission of Unusa to be the centre of entrepreneurs development and building in Indonesia. It can be concluded that Unusa is ready to become the centre of Rahmatan Lil Alamin entrepreneur development and building and will support the government program of One Pesantren One Product (OPOP)
\end{abstract}

Keywords: entrepreneur rahmatan lil alamin (enplus), entrepreneurship education system, one pesantren one product (OPOP).

\section{INTRODUCTION}

Entrepreneurship is a science relating to one's value, ability and behavior facing any challenge of life (effort). Entrepreneurship also a science of ability of creating something new and different. Entrepreneurship is the science of one's art, behavior, feature, characteristics and personality of person to have an ability to realize ideas (Zimmerer and Scarborough, 1998).

University is a place where invention and innovation can grow. To help students and graduates to have maximal potentials to be creators and innovators, some support must be provided. This is in line with the opinion of Leon et al (2007) who states that there are some social factors that may influence one's decision to take a career as an entrepreneur, among others are his education, physical infrastructure, entrepreneur support service and university specific support mechanism, such as providing facility and place for students to develop its entrepreneur ability.

Therefore, Nahdlatul Ulama Surabaya University (Unusa) as one of the universities in Indonesia that has a strong vision to prepare a generation of Rahmatan Lil Alamin having the spirit of entrepreneurship based on Islamic values in its implementation always gives some guidance to the students starting from recognizing, inspiriting up to implementing the entrepreneurship. The era of digital development nowadays surely will encourage the students to 
be the strategic agent of change in building the Indonesian nation and economy in future. Moreover, up to the next ten years, Indonesia will enjoy the demography bonus or momentum where Indonesian population will be dominated by productive age (15-64 years old person) population that will reach 70\% (Bappenas, 2017).

The Rector of Unusa, Prof Achmad Jazidie, M.Eng, states that Pondok Pesantren has extraordinary power of entrepreneurship, that is why it is very suitable that Governor of East Java Province, Khofifah Indar Parawansa has a superior program "One Pesantren One Product (OPOP)". This program is expected to produce modern pesantren products that will be managed by the Santris. To assist the development of modern pesantren entrepreneurship products, some institutions are required to give some assistance. The santris or the actor of entrepreneurship need some guidance to have proper concept and access to marketing, packaging techniques, price strategies up to financial statement preparation.

Furthermore, the government of Republic of Indonesia has decided to develop Santripreneur Program that will make Pondok Pesantren as the source of new entrepreneurship pioneers and the centre of micro, small and medium industrial sectors growth. During the year of 2014-2015, there are 28961 Pondok Pesantrens spread out throughout the entire area of Indonesia with the number of students of more than four million people (NU online, 2017).

From Islamic perspectives, entrepreneurship constitutes the life aspect that is grouped into muamalah issues, namely issues close to horizontal relationship or interpersonal relationship that will be accounted later in the hereafter living (akhirat), Entrepreneurship is considered ibadah (good deed) that will produce reward (pahala) if it is correctly conducted. From the economical aspect the objective of entrepreneurship activity is to become the part or deeds or activities as instructed by Allah SWT to all human beings, namely to do goo to others, love each other, and have each other in doing good deeds.

Nahdlatul Ulama University was established in 2013, yet in its relative young age, this university with its Islamic values is supported by an with 33 years experience in the sector of education institution management, namely Sekolah Tinggi Ilmu Kesehatan Yayasan Rumah Sakit Islam/STIKES YARSI (Medical School College of Islamic Hospital Foundation) and the biggest Islamic organization in Indonesia, Nahdlatul Ulama (NU).

The objective of this paper is to analyze the readiness of Unusa,a University with Islamic values under Nahdlatul Ulama to develop Entrepreneurship Education Ecosystem. It is expected that this paper may contribute to find what things need to be optimized in terms of making policy for entrepreneurship ecosystem establishment in Unusa. And for academicians, this paper can be regarded as one of the referential materials in establishing entrepreneurship education ecosystem in Universities.

\section{THEORETICAL BASIS}

Brush (2014) states that to produce students having the spirit of entrepreneurship, running start-up, realizing university venture and also bringing benefits to the community, an ecosystem known as entrepreneurship education ecosystem is needed. The description of Brush's statement is as hereunder: 


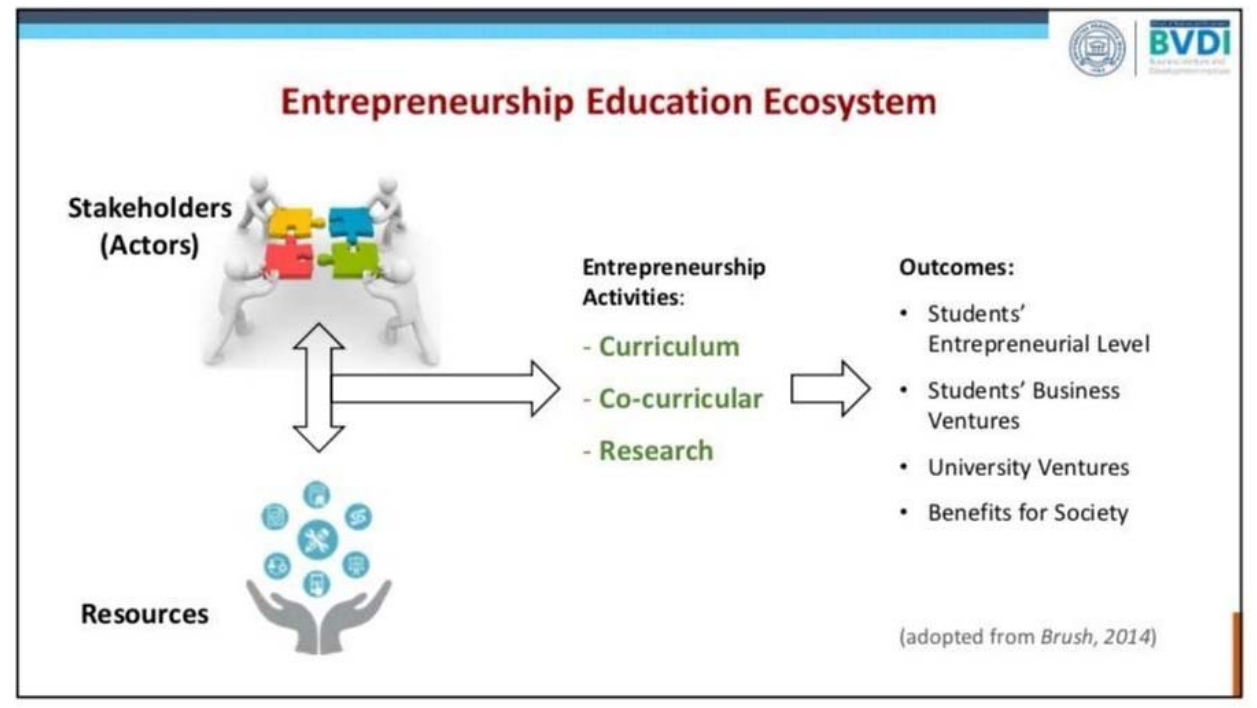

Picture 1 Entrepreneurship Education Ecosystem (Brush, 2014)

Entrepreneurship education ecosystem consists of:

\section{Stakeholders (actors)}

Stakeholders are the parties who have the authority to make decision or policy that may support entrepreneurship activities, whether from the university or external party, such as: management and supporting staff, lectures, teachers, instructors, tutor; students; network including parents, alumni, business communities, government, etc.

2. Resources

The resources of the paper include culture, policies, rule, sop; intellectual capital, patent, brand knowledge, etc; organization partnership, information system and software, potential demands/markets, financial resources, infrastructure, machine equipment etc., and materials.

3. Entrepreneurship activities

Entrepreneurship activities are activities that are conducted by civitas academy to develop the student spirit of entrepreneurship, in the form of curriculum, co-curricular activities and research.
- Curriculum, namely entrepreneurship education curriculum in university. There are some entrepreneurship education curriculum, for instance in the form of entrepreneurship course, entrepreneurship based courses (more than one core course) basic and obligatory courses prevailing for all faculties in the university, in the entrepreneurship concentration, department of entrepreneurship up to the faculty of entrepreneurship.

- Co-curricular activities are supporting activities for the development of students' spirit of entrepreneurship such as entrepreneurship clinic, training, workshop, seminar and business ideas competition and business plan competition.

- Research can be researches with topic of entrepreneurship, the research output can be used for the basis of decision or policy making relating to entrepreneurship among the students or Micro, Small and Medium Enterprises. 


\section{Outcomes}

Outcomes are the outputs of entrepreneurship activities conducted by the university, that are in the form of student's entrepreneur level, student's business level, university's venture and benefits for the society.

- Student's entrepreneur level refers to the stage where the students enter entrepreneurship stages, such as recognizing, inspiriting up to implementing the entrepreneurship.

- Student's business level means business level developed by the active students, including stages of ideas, start-up, growth, scale and maturity.

- University venture can be a company established by the university to produce products/services to be the outcome of students and lecturers researches.

- Business for society is the benefits felt directly by the society, such as getting variable quality products/services subject to need of the society.

\section{METHOD}

The methods applied in this paper is library research. The identify the validity of a research several techniques are applied. In this paper, the writer uses a library research method with the intention to find more deep data relating to the theme of the research to find temporary answer of the problem found before conducting the research. The method of searching, collecting and analyzing sources of data to be processed and presented in the form of library survey report based on writings, including researches that have or have not been published. In this paper the writer has applied a library research method with the objective to find some references relating to the concept.

\section{DISCUSSION}

In this part, the implementation of entrepreneurship education ecosystem in Unusa will be further elaborated.

\section{Stake Holder (Actors)}

- It is no doubt that the Rector and Heads of faculties in Unusa have a very strong commitment to produce creative Entrepreneur Rahmatan Lil Alamin (EnPlus). This is proven from the implementation of entrepreneurship courses in the six faculties within Unusa environment. Lecturers who teach entrepreneurship courses are those who are able to give entrepreneurship experience to the students. They consist of practitioners and also lecturers and at the same time also practitioners

- The support of Ministry of Research, Technology and Higher Education (Kemenristek Dikti) to the development of the Students' spirit of entrepreneurship in the form of Program Kreativitas Mahasiswa/PKM (Student Creativity Program), Program Kreativitas Mahasiswa - Kewirausahaan/PKM-K (Student Creative Program in the Entrepreneurship) and Pengabdian Kepada Masyarakat/ PKM-M (Students Service for Community) and Program Kompetisi Bisnis Mahasiswa Indonesia/PKBMI (Indonesian Student Business Competition Program) of 2018.

- The cooperation with the provincial government of East Java in realizing the program of "One Pesantren One Product (OPOP)" that is created by the Provincial Government of East Java under the governor of East Java Province (Khofifah Indar Parawansa). International Council for Small Business (ICSB) is the actor that is in cooperation with Unusa 
and PWNU. The first step that will be realized is to map Pesantrens that will be developed through Unusa network and regional management of Nadhatul Ulama (PWNU)

\section{Resources}

- Unusa nowadays is joined in an organization having care to the development of Small and Medium Enterprises such us International Council for Small Business (ICSB) and the activities that are conducted are researches, trainings and people empowerment.

- The Lecturers who teach entrepreneurship courses are also active in the Asosiasi Pendidik Kewirausahaan Indonesia/PERWIRA (Association of Indonesian Entrepreneurship Educators), therefore they can engage in the network and also exchange information about the learning of Entrepreneurship.

- Nowdays Unusa is trying to implement the idea of establishing Business Incubator as the place for the students to practice business. It is based on the principle that the existence of Business Incubator is expected to be able to give big potential for EnPlus to grow and one day it is expected to be the place for students' innovative products the students to get legal protection, such as copy right, Halal Certificate, Clinical Test and others. However, to encourage Unusa students potential in sectors of promotion, product exposure and direct experience having interaction with the buyers, Unusa since 2015 has established students cooperative managed by the students under the unit of Student Activity Program. This cooperative has been registered in the Ministry of Law and Human Rights of Republic of Indonesia No. 003412/BH/M.KUKM.2/2017.
- In line with the Digital Revolution in the product marketing sector, the entrepreneurship practice is now conducted digitally through online shop with address: enplus. unusa.ac.id

- Career and alumni center constitutes a potential partner that has supported and recommended the alumni of Unusa who are successful business players to be ready to be involved in the entrepreneurship practice of Unusa

- Potential Demand is widely open for products produced by students of Unusa because Indonesia is a country with the biggest Moslem population. Indonesia has very big potential for syariah economic development, as the new economical current having potential to encourage global economical growth.

- Cooperation with other Universities that have had experiences in Student entrepreneurship development, such as Universitas Airlangga (Unair) Institut Teknologi Seputuh Nopember Surabaya (ITS), and Universitas Ciputra (UC).

\section{Entrepreneurship Activities}

Entrepreneurship activities are activities conducted by the civitas academy in terms of developing the spirit of entrepreneurship for students, in the form of curriculum, co-curricular activities and research.

- Curriculum. the course of Entrepreneurship is conducted at six faculties and 17 study programs in Unusa, namely faculty of education science for three study programs, faculty of business economics for two study programs, faculty of medicine for two study programs, faculty of health for four study programs, faculty of engineering for one study program, faculty of midwifery and nursing 
for five study programs. From the six faculties, only the study program of management that has applied three courses with entrepreneurship basis and this study program becomes the role model for other study programs. Entrepreneurship based courses in the study program of management are basic entrepreneurship, first advanced entrepreneurship, and second advanced entrepreneurship. Following basic entrepreneurship, the students are expected to be able to make business plans, in the first advanced entrepreneurship the students are expected to be able to give inputs and assist micro, small and medium business, while in second advanced entrepreneurship, the students are targeted to be able to establish their own business.

- Co-curricular activities. Unusa students have entrepreneur community. Through this program the students having interest and strong will to be entrepreneurs are joined in E-marketing community. For those who have already have business can freely market their products in online shop that can be accessed by costumers throughout the entire area of Indonesia through website: enplus.unusa.ac.id.
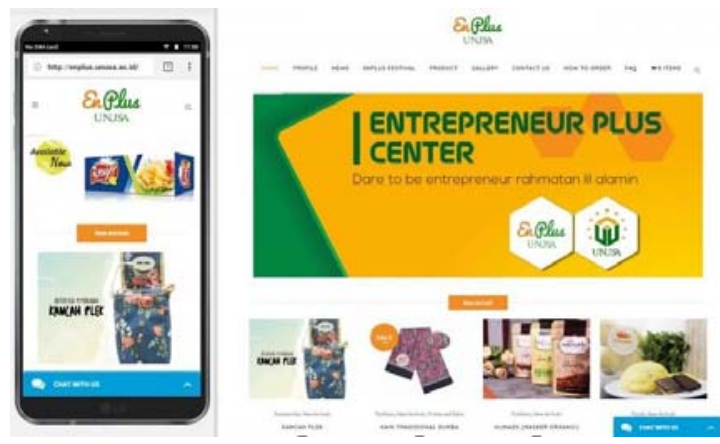

Picture 2 Display of Online Shop EnPlus www:enplus.Unusa.ac.id

Other activities of Enplus include to organize EnPlus Festival. An exhibition of Festi- val student business products, talk show with topics of entrepreneurship and business plan competition. These activities are open for public and followed by not only Students of Faculty of Economics and Business of Unusa but also other entrepreneurship students from other universities, namely Airlangga University, Institute Technology of 10 Nopember of Surabaya, and Ciputra University. The objective of inviting other university students is to give experience to Unusa students in developing their business network. By inviting the three university entrepreneur students to participate in the EnPLus Festival, hopefully marketing network for entrepreneur community among santripreneurs of Unusa is established. They can establish business synergy, share market science and information and support each other.

- Research: On April 18, 2019, ICSB and Unusa, a campus having big attention to young entrepreneurs development in Indonesia have signed a cooperation agreement. The cooperation is in the form of researches and also trainings about entrepreneurship of mcro, small, and medium enterprises in Pesantren in Indonesia in terms of supporting the implementation of the program "One Pesantren One Product".

\section{Outcomes}

- Student's entrepreneur level. At this level, Unusa students has entered into entrepreneurship stages including recognizing, inspiriting and implementing entrepreneurship. Recognizing, inspiriting, and implementing that are obtained from the courses or cocurricular activities. 
- Student's business level, the business levels engaged by active students including stage of idea, start- up, growth, scale up and maturity. At this level Unusa students are in the stages of idea and start-up. Considering that the number of Unusa students business in the stage of startup is increasing from year to year, the existence of business incubator in Unusa is really needed for the place to facilitate businesses developed by the students, so that they are properly directed, including how to meet investors or business partners and to get legal protection, such as form PIRT, HAKI, halal certificate, and clinical test.

- University venture. At present, Unusa has no university venture yet, seeing that Unusa is relatively young in age and still has no business incubator.

- Business for society. After three years of implementing entrepreneurship course, various students' innovative products have been produced/created. The emergence of student's innovative ideas up to the realization of marketable products are not separated from the assisting process conducted by the lecturers and practitioners. Therefore, the products are liked by the society because they can respond the people's need.

Analyzing the components of entrepreneurship education ecosystem in Unusa one by one, it is found out that from the four components, each component is almost fully completed. The importance of establishing business incubator and university venture in Unusa is really needed, however it is still understandable seeing that Unusa is a young university and the stages of entrepreneurship available in Unusa at present. Relating to the Unusa's support to government program, entrepreneurship education ecosys- tem in Unusa is ready to be set up as the centre of development and empowerment of Entrepreneur Rahmatan Lil Aalamin (EnPlus) and to support government program "One Pesantren One Product (OPOP)". From the explanation above, Entrepreneur Rahmatan Lil Alamin (EnPlus) is defined as the mindset, attitude, behavior, and ability to see the opportunity, innovate, and calculate risks to get profit with Islamic ways that good of all human beings, nature, and environment.

\section{CONCLUSION}

1. In spite of its young age of six years, Unusa has a strong commitment to prepare generation of entrepreneurs with Islamic values and in its implementation Unusa always gives debriefing to the students from recognizing, inspiriting and implementing entrepreneurship.

2. Unusa has had breakthroughs in developing entrepreneurship education ecosystem, and it is urgent to prepare to set up of Business Incubator considering that the number of Unusa students is getting more and more from year to year and the mission of Unusa to be the centre of EnPlus development and empowerment in Indonesia. Unusa is ready to be the centre of development and empowerment of Entrepreneur Rahmatan Lil Aalamin (EnPlus) and to support government program "One Pesantren One Product (OPOP)".

\section{REFERENCES}

Brush, Candida G. 2014. Exploring the Concept of an Entrepreneurship Education Ecosystem, in (ed.) Innovative Pathways 
for University Entrepreneurship in the 21st Century (Advances in the Study of Entrepreneurship, Innovation \&amp; Economic Growth, Volume 24) Emerald Group Publishing, Limited, pp.25-39

Leon J.A., Descals, F.J, Dominguez, J.F. (2007) "The Psychosocial Profile of the University Entrepreneur”, Journal of Psychology in Spain, 11 (1), 72-84.

Zimmerer and Scarborough. 2008. Entrepreneurship. Prentice Hall. https://www.bappenas.go.id; Bonus Demografi (Demography Bonus 2030-2040; Strategi Indonesia Terkait Ketenagakerjaan dan Pendidikan (Indonesian Strategies in relation to Manpower and Education). Retrieved 2 May 2019.

www.nu.or.id; Pesatnya Perkembangan Pesantren di Indonesia (The Rapid Development of Pesantren in Indonesia). Retrieved 2 May 2019. 